\title{
On morphology of Tanyderus pictus (Diptera: Tanyderidae) pupa and adult from Chile
}

\author{
О морфологии куколки и имаго Tanyderus pictus \\ (Diptera: Tanyderidae) из Чими
}

\author{
Elena D. Lukashevich, Dmitry E. Shcherbakov \\ E.А. Аукашевич, А.Е. Щербаков
}

Borissiak Paleontological Institute, Russian Academy of Sciences, 117997 Moscow, Russia. elukashevich@hotmail.com, dshh@narod.ru Палеонтологический институт им. А.А. Борисяка РАН, 117997 Москва, Россия.

KEY WORDS: living fossils, rearing, xylophagy, chaetotaxy, mouthparts, SEM.

КЛЮЧЕВЫЕ СЛОВА: живые ископаемые, выведение, ксилофагия, хетотаксия, ротовые органы, СЭМ.

ABSTRACT. The male and female pupae of Tanyderus pictus Philippi, 1865 are described, diagnosed, and illustrated for the first time from the specimens collected in Chile. The pupa is distinct from the others known for this family in the cylindrical thoracic horns with the cup-shaped plastron plate at apex, middle leg sheaths shortest, and pairs of protuberances with one central seta surrounded by numerous shorter chaetoids on tergites II-VII. The pupation always occurs inside a log or branch, in the same chamber where larva resided and at least sometimes adult emerges inside the trunk, just where pupation occurred. Several larvae pupated in laboratory and two females emerged, confirming our earlier identification of the larvae as T. pictus and their xylophagy. Photographs of live pupae and female of $T$. pictus are included. The female mandibles of $T$. pictus are well developed, sclerotized, and finely toothed along apical margin. The halter of $T$. pictus and some other tanyderids is provided with a short anterobasal projection corresponding to the prehalter of Ptychopteridae.

РЕЗЮМЕ. Куколки самцов и самок Tanyderus pictus Philippi, 1865 впервые описаны и проиллюстрированы по собранным в Чили экземплярам. Куколка отличается от остальных, известных для семейства, цилиндрическими торакальными рогами с пористой пластинкой на вершине, сравнительно короткими средними ногами и наличием на тергитах II-VII пары выростов со щетинкой, окружённой хетоидами. Окукливание происходит внутри бревна или ветки, в той же камере, в которой обитала личинка, и там же может вылупляться имаго. В лаборатории несколько личинок окуклились и вывелись две самки, что подтвердило нашу предварительную идентификацию личинок как T. pictus и их ксилофагию. Приведены фотографии живых куколок и самок T. pictus. У самок T. pictus мандибулы хорошо развиты, склеротизованы и мелко зазубре- ны по вершинному краю. У T. pictus и некоторых других танидерид обнаружен короткий вырост на жужжальце, соответствующий прехальтеру Ptychopteridae.

\section{Introduction}

The family Tanyderidae, or primitive crane flies, is an ancient and archaic nematoceran group, known since the Early Jurassic [Ansorge, 1994; Skibińska et al., 2014]. Tanyderids have an amphitropical distribution with higher diversity in the Southern Hemisphere, and were even more widespread in the Mesozoic [Eskov, Lukashevich, 2015]. The family includes 38 extant species in 10 genera. Only three monotypic genera are known in South America, all in the temperate zone and all described from Chile: Tanyderus Philippi, 1865, Neoderus Alexander, 1927 and Araucoderus Alexander, 1929.

Knowledge of tanyderid immatures is sparse (for larvae see a review in [Lukashevich, Shcherbakov, 2014]). The larvae were first discovered and reared to pupa and adult in Protoplasa fitchii Osten-Sacken, 1860 by Crampton [1930] and Alexander [1930a]. Later the pupae collected together with larvae were described for Peringueyomyina barnardi Alexander, 1921 and Protanyderus margarita Alexander, 1948 [Wood, 1952; Knight, 1964]. However, larvae are usually found without pupae [Exner, Craig, 1976; Podeniene, Gelhaus, 2013] and only sometimes successfully reared to adults [Pilgrim, 1990]. To date, larvae are not described for the genera Araucoderus, Neoderus and Nothoderus Alexander, 1927, and pupae for these three plus Tanyderus, Radinoderus Handlirsch, 1909, Eutanyderus Alexander, 1928, and Mischoderus Handlirsch, 1909 (pupae of Eutanyderus wilsoni Alexander, 1928 and Mischoderus sp. were obtained but remain undescribed [Hinton, 1966; Pilgrim, 1990]). Tanyderid larvae, but 
not yet pupae, are found in the fossil state [Lukashevich, Krzemiński, 2009].

The larvae of all three genera, which pupae are described, Protoplasa Osten-Sacken, 1860, Protanyderus Handlirsh, 1909 and Peringueyomyina Alexander, 1921 , occur in the hyporheic zone of sand- and cobblebottom rivers and streams; these pupae were found in drier ridges above the water, to where larvae migrate prior to pupation. No one pupa of xylobiotic genera was described yet.

The type genus of the family Tanyderidae was described a century and a half ago [Philippi, 1865], however up to now this monotypic genus is very rare in collections and only a dozen of adults is known [Alexander, 1936; I.R. Madriz, pers. comm., 2014]. In 2014 we discovered and described tanyderid larvae from logs submerged in streams among Nothofagus forests in the national parks Alerce Andino and Nahuelbuta, Los Lagos and Araucania regions, Chile [Lukashevich, Shcherbakov, 2014]. The larvae were identified as ?Tanyderus pictus based on their $\mathrm{COI}$ gene sequences being strongly different from those of adult Araucoderus gloriosus (Alexander, 1920), the only other tanyderid species known from the region. However no adults or pupae of T. pictus were collected by us in 2014. In January 2015 in the national parks Alerce Andino and Alerce Costero, Los Lagos and Los Rios regions we again collected many larvae and also in the former park a pupal cast and a mature pupa of T. pictus. Of numerous larvae from the latter park four pupated in laboratory, one very soon and three several months later, and two $T$. pictus females emerged (Figs 1-4). Our new data confirm the earlier identification of the larvae as $T$. pictus and their xylophagy.

\section{Material examined}

\section{Tanyderus pictus Philippi, 1865}

LARVAE: Alerce Andino National Park, sector Sargazo, Lenca

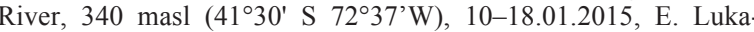
shevich; Alerce Costero National Park, sector Chaihuin, 2-4 km E

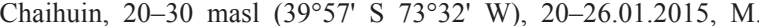
Chertoprud, E. Lukashevich.

PUPAE: Alerce Andino National Park, sector Sargazo, Lenca River, 340 masl, 1 male pupal exuvium \#1 and 1 female pupa \#2, 17.01.2015, E. Lukashevich; Alerce Costero National Park, sector Chaihuin, $2 \mathrm{~km}$ E Chaihuin, 20 masl, 1 male pupa \#3, 25.01.2015 (larva pupated in laboratory); 2 female pupal exuvia \#4 and \#5, 8.03. $2015,12.03 .2015$ (larvae pupated in laboratory); 1 female pupa \#6, 1.05.2015 (larva pupated in laboratory), E. Lukashevich.

ADULTS: Alerce Costero National Park, sector Chaihuin, $2 \mathrm{~km}$ E Chaihuin, 20 masl, 2 females \#4 and \#5, 15.03.2015 and 19.03.2015 (emerged as adults from larvae pupated 8.03.2015 and 12.03.2015 in laboratory).

\section{Methods}

All field-sampled and reared specimens were put in $70 \%$ ethanol, one reared female was pinned.

The larvae were transferred to the laboratory along with their native substrate. They were kept in plastic boxes with Nothofagus branches (10-20 cm long and 2$6 \mathrm{~cm}$ in diameter, with or without bark); the water covered only the container bottom, without any circulation; most part of branches were wet, but out of water. We maintained containers at ambient room temperature of the laboratory at day and kept cool at night $\left(15^{\circ} \mathrm{C}\right)$; the containers were checked daily for pupated larvae (later for reared adults) and misted with water.

Photographs were taken using a Leica M165C stereomicroscope with a Leica DFC425 digital camera, Z-stacked using Helicon Focus 4.10 Pro and adjusted in Adobe Photoshop ${ }^{\circledR}$ CS3 10.0. For scanning electron microscopy (SEM) two pupal exuvia were dehydrated in graded alcohols, soaked in hexamethyldisilazane, and dried. Scanning electron micrographs of uncoated and gold-coated specimens were taken with a Tescan Vega microscope using backscattered electron (BSE) and secondary electron (SE) detectors.

The morphological terminology generally follows that of Crampton [1930] and Wood [1952].

Abbreviations used in the figures

al anterior lateral or pleural setae and seta-bearing processes ant antenna

apa anterior parietal setae and processes

as antesternite

asp postabdominal spiracle

at antetergite

atg anterior tergal seta

b bubbles

ba raised basalar area and setae

bc basicercus

cl clypeus

dc disticercus

es epistomal setae

f frontal setae and processes

fl fore leg

fs frontal clefts corresponding to frontal sutures

gc gonocoxite

gs gonostyle

$\mathrm{h}$ thoracic horn

hl hind leg

hp hypopharynx

1 labrum

lp labial palpus

lpr lateral processes

md mandible

$\mathrm{ml}$ middle leg

mn metanotum

$\mathrm{mp}$ maxillary palpus

$\mathrm{mx}$ maxilla

pf prefrontal setae

ph prehalteral setae

pl posterior lateral or pleural setae and processes

po preocular setae

ppaposterior parietal setae and processes

ps posterior sternal setae

pt posterior tergal setae

sc scutal setae

sg genal or subgenal setae

sp rudimentary spiracle

tg tegular region and setae

vp verriculate protuberance 


\section{Localities, habitats and behaviour}

The larvae were collected in the national parks Alerce Andino and Alerce Costero (Figs 5-6), in Nothofagus-dominated forests containing other broadleaved trees and rare conifers (Fitzroya).

The site in Alerce Andino, the same one as in 2014, was the forested fast-flowing Lenca River, at 340 masl, with a shingle bottom, abundant detrital material, most of which is woody and probably originates from abrasion of drifting trees during high water levels, and almost whole dead Nothofagus trees, occasionally with preserved bark. The river in that area is about $10 \mathrm{~m}$ wide and $0.4-1 \mathrm{~m}$ deep, with occasional diagonal and midchannel bars. Some logs with larvae laid on the fastflowing midstream, some in the quiet backwater, all logs possessed bark, and some of them were out of the water when its level dropped. About 20 larvae were collected from 8 logs in three sites (two extreme sites approximately $1 \mathrm{~km}$ apart) during one week. In all three sites several adults of Araucoderus gloriosus were captured, and again no adult Tanyderus pictus though a male pupal cast and a mature female pupa were found, so adults of the latter genus were already "on wing" in mid-January.

In 2014 we have found only two logs with larvae in Alerce Andino, and in both larvae lived without chambers crawling under the bark in a smelly semiliquid pulp. Such conditions turned out to be optional: in 2015 we discovered larvae in deep straight chambers under the surface of wood as well as in branched chambers just under the bark with numerous crushed wood fragments inside. The larvae collected in Alerce Andino in 2015 are similar in size to those collected there a year before [Lukashevich, Shcherbakov, 2014].

The Nothofagus branch $(0.8 \mathrm{~m}$ long and $8 \mathrm{~cm}$ in diameter) which yielded the male pupal cast \#1 and mature female pupa \#2 laid on the horizontal support of the old wooden bridge (clearly brought by spring flood, being absent one year before, Fig. 5), with pupal cast \#1 occurring in the dry part of the branch and pupa \#2 in a narrow chamber under a knot near the boundary of dry part (Fig.1, pupa \#2 in situ, bark removed). The pupal cast \#1 didn't protrude from the branch surface as one can see in various limoniid pupae, and was found near a larval exuvium retaining the head capsule in a narrow chamber under the bark. Besides tanyderids, only numerous red larvae of Chironominae and pupae of $\mathrm{Co}-$ leoptera were found in this branch.

The sector Chaihuin of Alerce Costero National Park is about $40 \mathrm{~km}$ from Los Ulmos, Valdivia where the holotype of T. pictus was captured in March 1865. In January 2015 no adult Tanyderidae was collected by us, only numerous larvae. Almost two dozen of logs with larvae were found during one week in two small forested creeks (sandy bottom, 0.1-0.2 m deep, $2 \mathrm{~km}$ apart) and in shallow backwaters of the large Chaihuin River and its tributary (sand-mud substrate at the water's margin near gravel-cobble main bed, $<0.5 \mathrm{~m}$ deep).
Some of these branches were with bark and some without, some were solid and some saturated, decomposed, easily disintegrating into whitish fibres. The most productive $\log$ ( $1.5 \mathrm{~m}$ long, $25 \mathrm{~cm}$ in diameter) that yielded more than 70 larvae of second to forth instars was without bark, with very soft, decomposing outer layers. Numerous larvae and pupae of non-aquatic Coleoptera, Neuroptera and Diptera were found together with tanyderid larvae, some of the latter dwelling in the beetle galleries partly filled with frass but always near the solid wood still light in colour.

Larvae from Alerce Costero are clearly larger then those from Alerce Andino and on average larger than those from the Nahuelbuta National Park [Lukashevich, Shcherbakov, 2014]: Alerce Costero: 4th instar $(\mathrm{n}=7)$ : head length 2.45-3.10 (mean 2.84) mm, width 2.1-2.55 (mean 2.4) mm, maximum total body length $55 \mathrm{~mm}$ including $8.5 \mathrm{~mm}$ tail filaments; 3 rd instar $(\mathrm{n}=16)$ : head length 1.65-1.90 (mean 1.75) mm, width 1.4-1.65 (mean 1.47) $\mathrm{mm} ; 2$ ind instar $(\mathrm{n}=5)$ : head length $1.00-1.65$ (mean 1.35) mm, width 0.9-1.45 (mean 1.2) mm.

We tried to rear one dozen of large larvae of forth instar just in Alerce Costero, but only one \#3 found on 23 January in a narrow chamber, situated under a knot of short branch ( $25 \mathrm{~cm}$ long, $5 \mathrm{~cm}$ in diameter), pupated very soon, on 25 January in the same chamber (Fig .2). The male pupa \#3 maturated for a week, with adult colouration and setation becoming visible (Fig. 29), but died on 1 February occasionally damaged by another larva. Three larvae pupated in laboratory inside the branches: \#4 and \#5 probably on 8 and 12 March (pupae were seen on 11 and 16 March, respectively), and \#6 on 1 May. The pupae \#4 and \#5 were reared into females of T. pictus on 15 and 19 March, respectively (Figs 3, 4, 711); the female pupa \#6 died on 11 May. The larva \#4 escaped into chambers existing under the bark on 1 February and dwelt inside up to the pupation (probably on $8 \mathrm{March}$ ); the larva was checked once per two weeks by removing the bark (was found in a fresh self-dug chamber near a knot) or outer layer of wood (was found in an old long chamber directed into empty middle part of the branch); when disturbed, the larva retreated into another chamber and never returned to the previous one in spite of putting back the bark or piece of wood. The larva \#5 was inside the branch since the end of January in Alerce Costero and wasn't seen before pupation: the pupa occurred on the surface of the branch on 16 March already with dark pattern on the wings, therefore several days after pupation. The larva \#6 crawled in the water layer under the branch and wood fragments six weeks (with dark gut content), sometimes hided under the bark partly or entirely and later crawled outside. This larva hid inside finally only in the middle of March, six weeks before its pupation on 1 May, and almost every day a new portion of crushed wood fragments appeared at the exit of its self-dug chamber, which was situated near a knot and later extended around the knot, subparallel and close to the surface (the light of illuminator fibres from outside was visible inside). During a month one can see the head of larva directed to the chamber exit, and later 


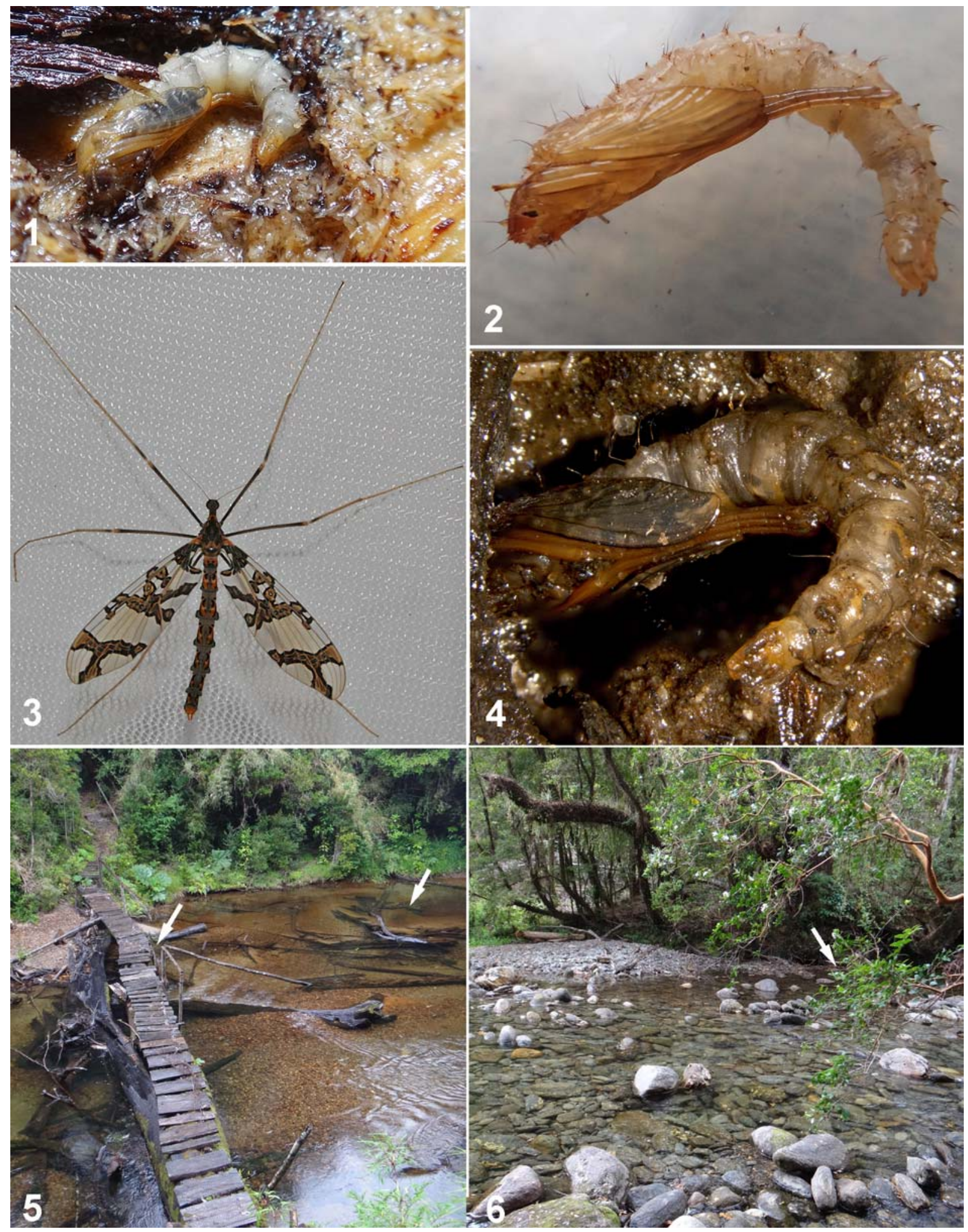

Figs 1-6. Live Tanyderus pictus and their habitats: 1 - female pupa \#2 in situ (Alerce Andino, 17.01.2015); 2 - freshly moulted male pupa \#3 (Alerce Costero, 25.01.2015); 3-4 - female \#5 (photographs by R. Rakitov) and its pupa (Alerce Costero, reared from larva in laboratory, 19.03 and 18.03.2015); 5 - Lenca River, Alerce Andino; 6 - tributary of Chaihuin River, Alerce Costero; arrows, location of finds of larvae and pupae.

Рис. 1-6. Живые Tanyderus pictus и их местообитания: 1 - куколка самки \#2 in situ (Алерсе Андино, 17.01.2015); 2 свежевылупившаяся куколка самца \#3 (Алерсе Костеро, 25.01.2015); 3-4 - самка \#5 (фото Р. Ракитова) и ее куколка (Алерсе Костеро, выведены из личинки в лаборатории, 19.03 и 18.03.2015); 5 - р. Ленка, Алерсе Андино; 6 - приток р. Чайуин, Алерсе Костеро; стрелки, места находок личинок и куколок. 
the thoracic horn and part of cephalothorax of the pupa at depth $2 \mathrm{~cm}$, whereas the major part of the larva or pupa was situated "behind the corner", beyond the knot and was invisible. When disturbed (e.g. by the light of illuminator), the larva as well as pupa \#6 retreated "behind the corner" becoming invisible through the chamber exit.

The pupation in all three cases occurred in the same chamber where the larva dwelt (as a result, the larval exuvium was always found nearby). The pupa \#4 quickly reared in the same place where larva and pupa resided and pupal and larval exuvia were found nearby. The pupa \#5 crawled onto the side saw cut of the branch and was positioned with the cauda up anchoring by cephalothorax. The pupa \#6 crawled out of the chamber on the tenth day, was positioned with the cauda up, however in the night returned into its chamber and died inside.

Summarizing, $T$. pictus, once considered quite rare, can be abundant (about one hundred larvae of various instars in a single $1.5 \mathrm{~m} \mathrm{log}$ ) in suitable lotic habitats, including rivers and streams in Nothofagus-dominated forests, with trees growing close to the water. Like in many other xylobiotic Diptera [Krivosheina, Mamajev, 1967] several females may lay eggs into the same part of a fallen rotting log, so a colony is formed; females probably oviposit for a long time, not simultaneously, as a result the colony consists of larvae of various ages. The larvae dwell in logs (more than $20 \mathrm{~cm}$ in diameter) and small branches $(3-5 \mathrm{~cm}$ in diameter) with and without bark, at various stages of wood decay (solid or saturated, decomposed, easily disintegrating into whitish fibres). Larvae move easily not only in semiliquid pulp just under the bark but also through self-dug narrow chambers in the solid wood, sometimes with the abdominal apex forwards. As we can conclude based on laboratory rearing, larvae are semiaquatic but can survive for a long time outside the branch, in the water, provided with abundant decaying wood fragments on the bottom, though we didn't find any larvae outside the logs. Probably at least a month before pupation the larva hides inside the $\log$ and in this case its relatively short chamber is positioned not far from its surface. However usually larvae live inside logs during the whole larval life, and their chambers become longer (sometimes branched) and much deeper into the wood with the age. Larvae push debris out of their chambers, from a short chamber just onto the outside surface of the log lacking bark, or in the more usual long gallery just behind the larva, nearer to the gallery exit (in Fig. 1 numerous crushed wood fragments puddled by larva are visible all round the pupa). Pupation always occurs in the wood, in the same chamber where the larva resided, and at least sometimes the adult emerges inside, where pupation occurred. Duration of pupal stage is no less than 7 , probably $8-10$ days. Probably larvae never pupate in underwater logs, only in drier parts of partly submerged logs or after the water level dropping in summer.

Most of behaviour peculiarities noted here, are similar to those described recently in detail for another wood-inhabiting, semiaquatic fly Axymyia furcata McA- tee, 1921 [Wihlm, Courtney, 2011]. It is worth to mention that when tanyderid larvae were still unknown, it was the axymyiid larvae found in saturated logs were mistakenly referred to Tanyderidae [Alexander, 1927], therefore Alexander and Crampton "began a critical survey of all saturated logs, stranded and imbedded in the earth at the stream margin" where a large swarm of Protoplasa was seen earlier [Alexander, 1930a]. However the first tanyderid larvae were discovered there in sandy gravel at the water's margin, and only many years later it became obvious that saturated logs indeed are a suitable habitat for semiaquatic larvae of several genera of Tanyderidae [Colless, McAlpine, 1970; Krzemiński, Judd, 1997; Judd, 2004].

Kovalev [1984] supposed the dwelling deep in the submerged wood or bottom substrate to be the oldest life mode for dipteran larvae, and explained the absence of the fossil Late Triassic and Early Jurassic dipteran larvae by such mode of life unfavourable for burial. Now in spite of their real rarity the immatures of Diptera are known since the Middle Triassic [Lukashevich et al., 2010], however larvae of Tanyderidae are exceptionally rare in the fossil record-so far only two larvae in one Late Jurassic locality [Lukashevich, Krzemiński, 2009].

\section{Morphology of Tanyderus pictus}

Adult. Two reared females from Alerce Costero (Figs 3, 7-11) fit the descriptions of the holotype (male?) from nearby Los Ulmos [Philippi, 1865; Alexander, 1913] and allotype female from Concepción [Alexander, 1929, 1930b], their wing venation and colour pattern being as figured by Williams [1933; fig. 34], but their size smaller than in historical specimens: total length $23-24 \mathrm{~mm}$, wing length $21-22 \mathrm{~mm}$, compared to $35 \mathrm{~mm}$ and $31.5 \mathrm{~mm}$ in the allotype. Description of the adult is supplemented with several characters:

Short hairs between ommatidia (as in all Tanyderidae [Alexander, 1927]). Female dichoptic, interocular distance about two diameters of ommatidia; posterior part of cranium with long dense setae (Figs 12,15). Clypeus $c l$ very strong, with several dozen of marginal and distal setae (Figs 12,14). Antenna with 22-25 flagellomeres (22 in female \#5; Fig. 11). Mouthparts moderately elongate. Labrum $l$ sclerotized, subequal to clypeus, with aperture of unclear nature at base (Figs 13-14). Mandibles $m d$ and maxillae $m x$ rather broad blades obliquely truncate apically; mandibles overlapped, sclerotized, apex acute, inner apical margin dark and minutely denticulate; maxillae with sclerotized shaft near outer margin and weakly sclerotized inner area, apex narrowly rounded, inner apical margin translucent with submarginal row of minute, short, spaced ridges; hypopharynx $h p$ trough-like, sclerotized, microscopically denticulate on margin, with dark salivary canal. Maxillary palpi $m p$ elongate, densely pubescent; labial palpi, or labellae lp large, two-segmented; mandibles and maxillae slightly shorther than labrum and hypopharynx, two latter somewhat protruding between labellae in repose (Figs 13, 20-21). Wing venation: usually Rs forked into $\mathrm{R}_{5}$ and $\mathrm{R}_{2+3+4}$, but in our specimens origin of $\mathrm{R}_{5}$ very close to origin of $\mathrm{R}_{2+3}$ and sometimes even just beyond it (in the case $\mathrm{R}_{4+5}$ shorter than crossvein $r-m$ - in both wings of female \#5; Figs 3, 16). Halter with short anterobasal projection (Figs 22-24). Claws simple, arolium, empodium and pulvilli ab- 


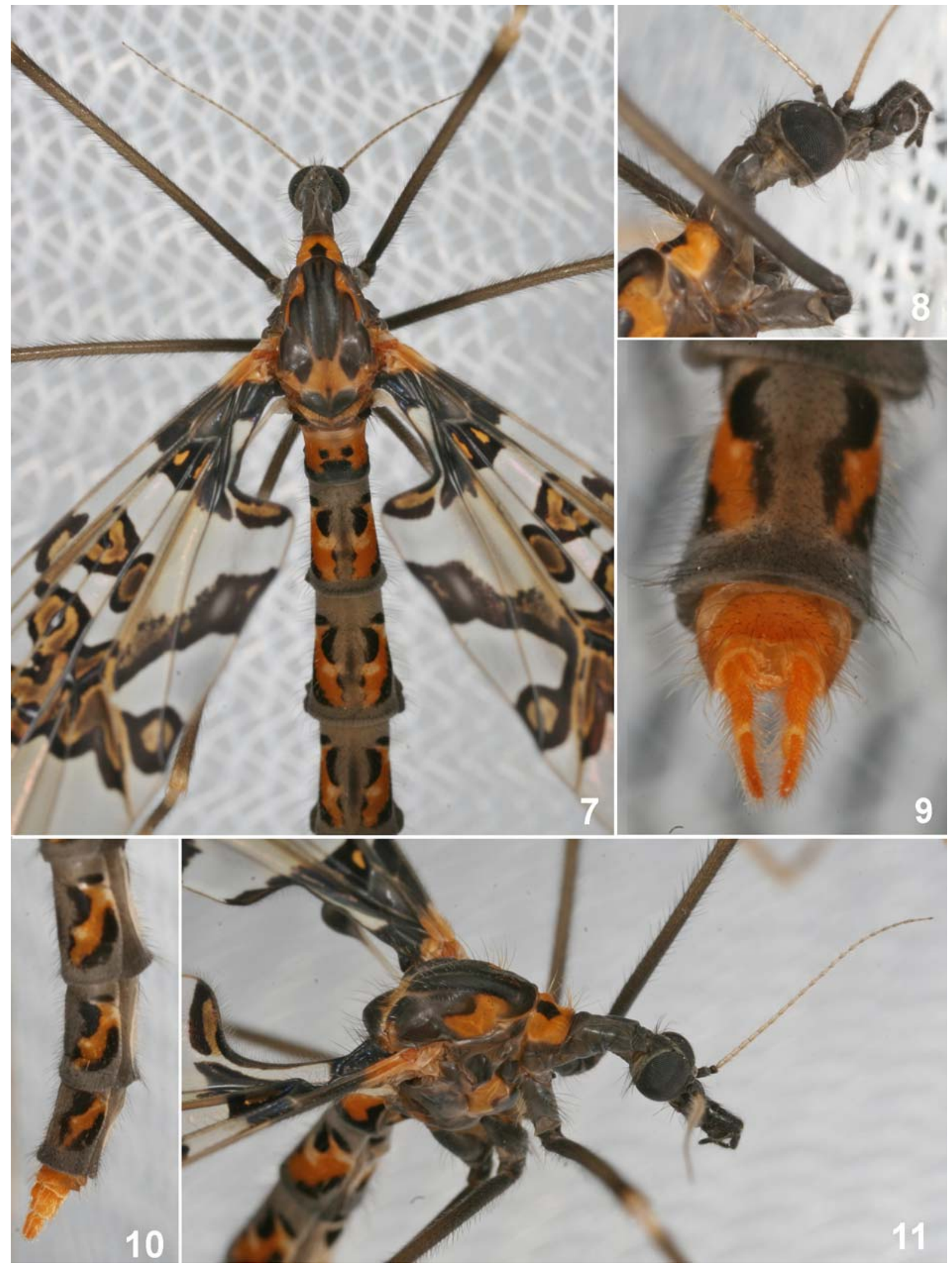

Figs 7-11. Live female T. pictus \#5 (Alerce Costero, photographs by R. Rakitov, 19.03.2015): 7 — habitus dorsally; 8 — head laterally; 9 - cauda dorsally; 10-11 — abdomen laterally; 11 - habitus laterally.

Рис. 7-11. Живая самка T. pictus \#5 (Алерсе Костеро, фото Р. Ракитова, 19.03.2015): 7 - общий вид сверху; 8 — голова сбоку; 9 - конец брюшка сверху; 10 - брюшко, сбоку; 11 - общий вид, сбоку. 


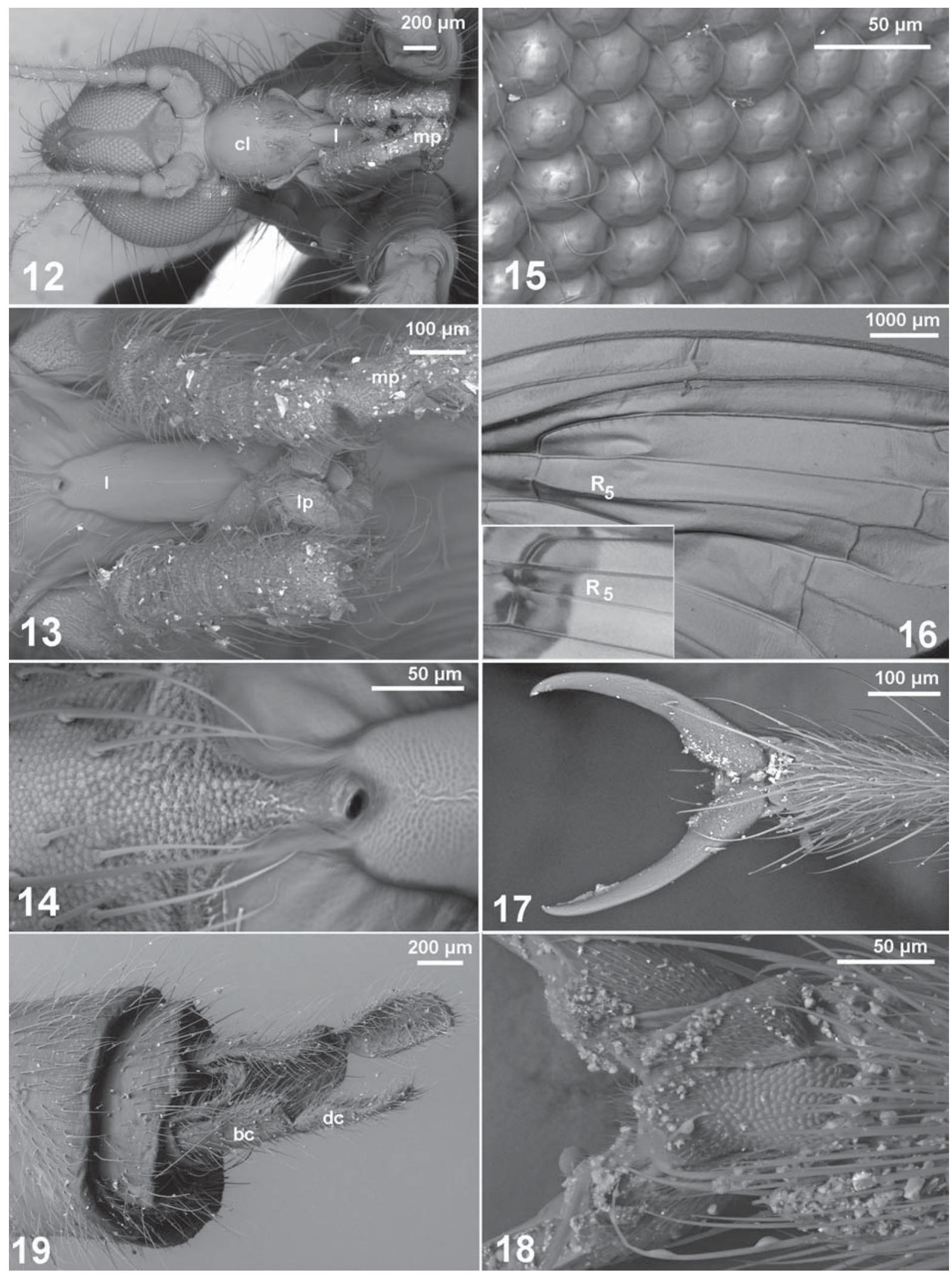

Figs 12-19. Female T. pictus \#5 (Alerce Costero; SEM, uncoated, BSE): 12-14 — head and mouthparts frontally; 15 — eye; 16 — part of wing (inset, female \#4, photograph, part of wing); 17-18 - claws dorsally and ventrally; 19 - cerci dorsolaterally.

Рис. 12-19. Самка T. pictus \#5 (Алерсе Костеро, СЭМ, без напыления, BSE): 12-14 — голова и ротовые части спереди; 15 глаза; 16 - часть крыла (врезка, самка \#4, фото, часть крыла); 17-18 - коготки сверху и снизу; 19 - церки сверху-сбоку. 


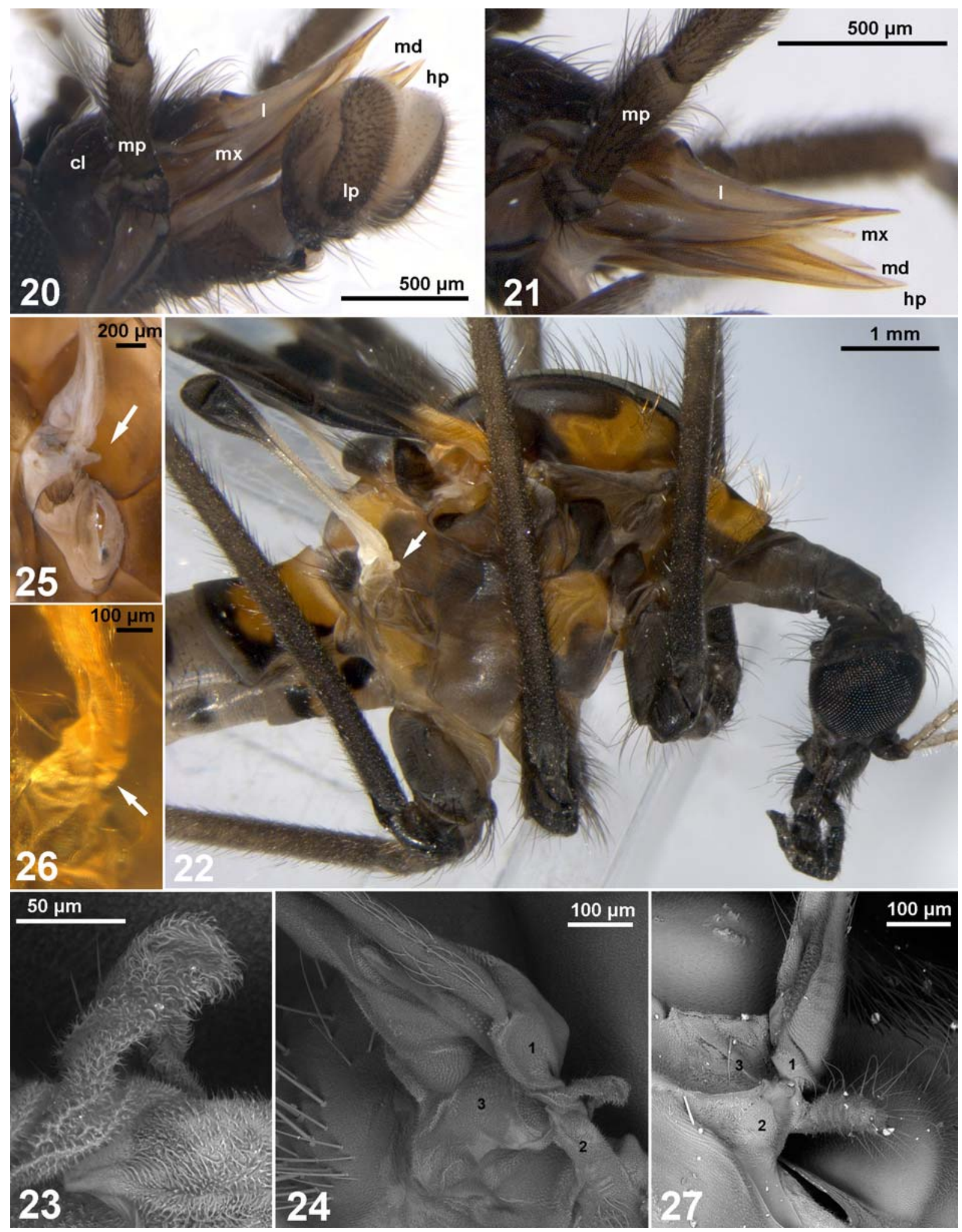

Figs 20-27. Details of adult: 20-24 - T. pictus; 25 - Araucoderus gloriosus; 26 - Macrochile spectrum; 27 - Ptychoptera handlirschi (Czizek, 1919); 20-21 — female \#4, mouthparts; 22-24 — female \#5: 22 — head and thorax laterally; 23 — rudimentary prehalter; 24-27 base of halter with (rudimentary) prehalter; 23-24, 27 - SEM, uncoated, BSE; arrow, rudimentary prehalter; homologous parts numbered.

Рис. 20-27. Детали строения имаго: 20-24 - T. pictus; 25 - Araucoderus gloriosus; 26 - Macrochile spectrum; 27 - Ptychoptera handlirschi (Czizek, 1919); 20-21 — самка \#4, ротовые части, 22-24-самка \#5: 22 - голова и грудь сбоку; 23 - зачаточный прехальтер; 24-27 - основание жужжальца с (зачаточным) прехальтером; 23-24, 27 - СЭМ, без напыления, BSE; стрелка зачаточный прехальтер; гомологичные части пронумерованы. 
sent (Figs 17-18). Female cercus orange, of two segments, basicercus $b c$ and disticercus $d c$, both relatively large and elongated (Figs 9-10, 19); in female \#5 one basicercus with abnormal narrow projection (Figs 9, 19).

In the mature pupa (with pharate adult inside) some details of adult habitus, colouration and setation characteristic of T. pictus are visible (Figs 4, 28-39): 22-25 flagellomeres (probably 26 in male); peculiar dark spots on yellow tergites and sternites; venation with Rs forking into $\mathrm{R}_{2+3+4}$ and $R_{5}$ with base of $R_{5}$ very close to nearest fork and two supernumerary veins in $\mathrm{r} 4$ and $\mathrm{r} 5$ cells; peculiar dark pattern on wing with pale distal triangle whereas the other pale areas of adult wing being grey and separated by pale stripes from dark distal Y-shaped and middle X-shaped bands and the base of wing; dark knob and pale stem of halter; dark femur and dark ring on tibia below pale knee, pale lower part of tibia and tarsus; yellow female cerci (orange in adult).

Pupa. The following characters, common to all the described tanyderid pupae, appear to be of the family level and thus are not repeated below: Thoracic horns equal in size. Sheaths of maxillary palpi very stout, five-segmented, bent upward (directed laterad and then cephalad). Abdominal tergites I-VII each with transverse row of strong setae on prominent tubercles near posterior margin, tergites VIII-IX in both male and female pupae with lateral processes (= fingerlike lobes of Wood).

DIAGNOSIS. Prominent setation on cephalothorax and abdominal tergites; no frontal horns or epistomal processes; thoracic horns small, almost cylindrical, with comparatively small, cup-shaped plastron plate at apex; tergites II-VII in middle part with pair of verriculate protuberances with one central seta surrounded by numerous shorter parallel chaetoids; leg sheaths overlapping, unequal in length, middle pair shortest, hind longest.

DESCRIPTION. Integument pale yellowish brown, cauda unsclerotized; in mature pupa grey pattern of adult visible on wings and body. Setation prominent.

Head (Figs 28-29, 34-35, 41, 50). Dorsal region of head without frontal horns, with longitudinal row of three long, strong tuberculate setae: frontal $f$, immediately dorsad of antennal origin and ventrad of frontal suture $f s$, anterior apa and posterior parietal ppa setae. Ventral region of head with two long, strong tuberculate setae in transverse row, prefrontal $p f$ and preocular $p o$, overlying clypeus and eyes of developing adult respectively, and pair of tuberculate genal or subgenal setae $s g$ (outer one thinner and not close to stout inner seta) near bend of maxillary palpus $m p$. Antennal sheath ant with apex pointed, laying back over ocular area and maxillary palpus, ending beyond wing base, longer in male, with 22-23 flagellomeres visible in female, 26? in male, its outer basal margin with several dilations, bubbles $b$. Epistomal region prominent, without epistomal processes, with two adjacent epistomal setae es on single tubercle near base of labrum sheath. Labrum sheath $l$ relatively short, tapering tube with truncate apex. Sheaths of mandible $m d$ and maxilla $m x$ (galea or lacinia of authors) with processes directed to labrum, both ending with pointed apex slightly distal to labrum tip in female and male (Figs 41, 50-51). Sheaths of maxillary palpus $m p$ long, with dilation corresponding to distal widening of palpomere IV and apex turned inwards along contour of antenna. Sheath of labial palpi $l p$ longer than broad, with pointed apex.

Thorax (Figs 34-35). Pronotum extensive, divided into antepronotum apn and postpronotum ppn; thoracic horn $h$ (Figs 42, 52-53) small, almost cylindrical, with brown distal part and comparatively small, cup-shaped plastron plate at apex; 1 strong tuberculate seta and 2 minute basalar setae $b a$ on elevated, flattened basalar lobe under horn base (Figs 33, $35)$. Mesonotum gibbous, nearly smooth, with 3 scutal setae $s c$ ( 2 strong tuberculate, one of them abnormal in male pupal cast \#1, and 1 short and thin, Fig. 43) and 3 tegular setae $t g$ on weak callosity above wing base (1 strong tuberculate and 2 minute, Figs 33-35). Metanotum $m n$ well developed, smooth, with 3 prehalteral setae $p h$ ( 1 strong tuberculate and 2 minute) and 2 strong inner and 1 thin outer lateral setae near halter sheath (Figs 30, 33, 35). Wing sheaths (Figs 29, 33) overlapping halter sheaths and reaching base of abdominal segment IV. Leg sheaths (Figs 28, 40) overlapping, unequal in length, middle pair shortest, hind one longest, reaching abdominal segment VI in male and base of segment $\mathrm{V}$ in female pupa.

Abdomen (Figs 30-32, 36, 39, 45). Anterior regions of segments, antetergite at and antesternite as without strong setae, only with uniform spinulose microsculpture and with 1 minute seta in bare spot on antesternite (Figs 45, 56-57, 6364). Tergites I-VII with 1 thin anterior tergal seta atg (Figs 45, 58 ) and (except for tergite I) verriculate protuberance $v p$ with one central seta surrounded by numerous shorter parallel chaetoids (Fig. 62), and in posterior row with 4 long tuberculate setae ( 1 medial $p t_{l}$ and 3 lateral posterior tergal $\left.p t_{2-4}\right)$; on tergite I (Fig.56) only minute spinules between posterior tergal setae, on tergite II-VII (Figs 44, 58-59, 61) additional spinules of various sizes, grouped by 1-3 spinules on prominences, decreasing in number on terminal segments $(3-5$ spinules on segment VII instead of 19-20 spinules on segment II in middle groups between setae $p t_{1}$ ). Pleurites I-VII (Figs 36, 38, 60) with small non-functional spiracle $s p$, uniform spinulose microsculpture and 4 setae: 1 strong tuberculate anterior lateral seta $a l$ just behind spiracle and 3 posterior lateral setae $p l$ in posterior row ( 2 strong tuberculate and 1 small between them). Sternites I-VII (Figs 37-38, 54, 63) with 2 posterior sternal setae, tuberculate inner $p s_{1}$ and small outer $\mathrm{ps}$, in posterior row; sternite VIII with 2 equal tuberculate setae $p s$ near base of lateral processes $l p r$ (Fig. 32). Postabdominal spiracle asp (Figs 37, 39, 46-47, 55) at base of lateral process lpr on tergite VIII, near small medial seta. Lateral process $l p r$ on tergite VIII twice longer than that on tergite IX, surface of both processes unsclerotized, with numerous spinules and smooth spot near tip (Figs 37-39, 46-49, 54); lateral process of tergite VIII with 2 strong tuberculate setae on outer surface proximally and 1 seta terminally. Segment X (Figs 31, 37-38, 46-47) with sheaths of cerci, divided into rigid basal and softer distal region (for basicercus $b c$ and disticercus $d c$ ) in both sexes. Genital sheaths of male undivided, though two-segmented adult structure (gonocoxite and gonostyle, basistyle and dististyle of Crampton) visible inside (Figs 32, 47).

MEASUREMENTS (mm). Alerce Andino. Female $(\mathrm{n}=1)$ : length total 19 , antenna 3.7 , cephalothorax 3.75 , thoracic horn 0.8, wing 5.8. Alerce Costero. Male $(\mathrm{n}=1)$ : length total 15.5, antenna 4.1 , cephalothorax 3.4 , thoracic horn 0.8 , wing 6.5 . Female $(\mathrm{n}=2)$ : length total $23-24$, antenna 3.2-3.5, cephalothorax 3.9-4.0, thoracic horn $0.8-0.85$, wing 7.0-8.0. Two exuvia examined under SEM are not included.

COMPARISON. Distinct from the other described pupae of Tanyderidae (i.e. from Protoplasa, Protanyderus and Peringueyomyina) in the presence of paired verriculate protuberances on tergites II-VII, cylindrical thoracic horns with a cup-shaped plastron plate at apex, and the middle leg sheaths shortest. Similar to African Peringueyomyina in the absence of frontal horns, presence of three uniform tuberculate setae dorsad of antennal base, and overlapping leg sheaths, but the latter genus is distinct in the shorter leg sheaths reaching only abdominal segment III and sclerotized cauda. It is unknown 
whether Peringueyomyina has apical plastron plate in thoracic horn or sheaths of cerci on segment $\mathrm{X}$ in male.

In its larval characters Tanyderus is similar to but distinct from Mischoderus, Radinoderus and Eutanyderus, and some species of these genera also have xylobiotic larvae. The pupae of three latter genera remain undescribed, except for the structure of thoracic horns in Eutanyderus [Hinton, 1966] which differs markedly from that of Tanyderus. Since the pupa of T. pictus is the first xylobiotic pupa known, one can expect to find significant differences from hyporheic pupae. However

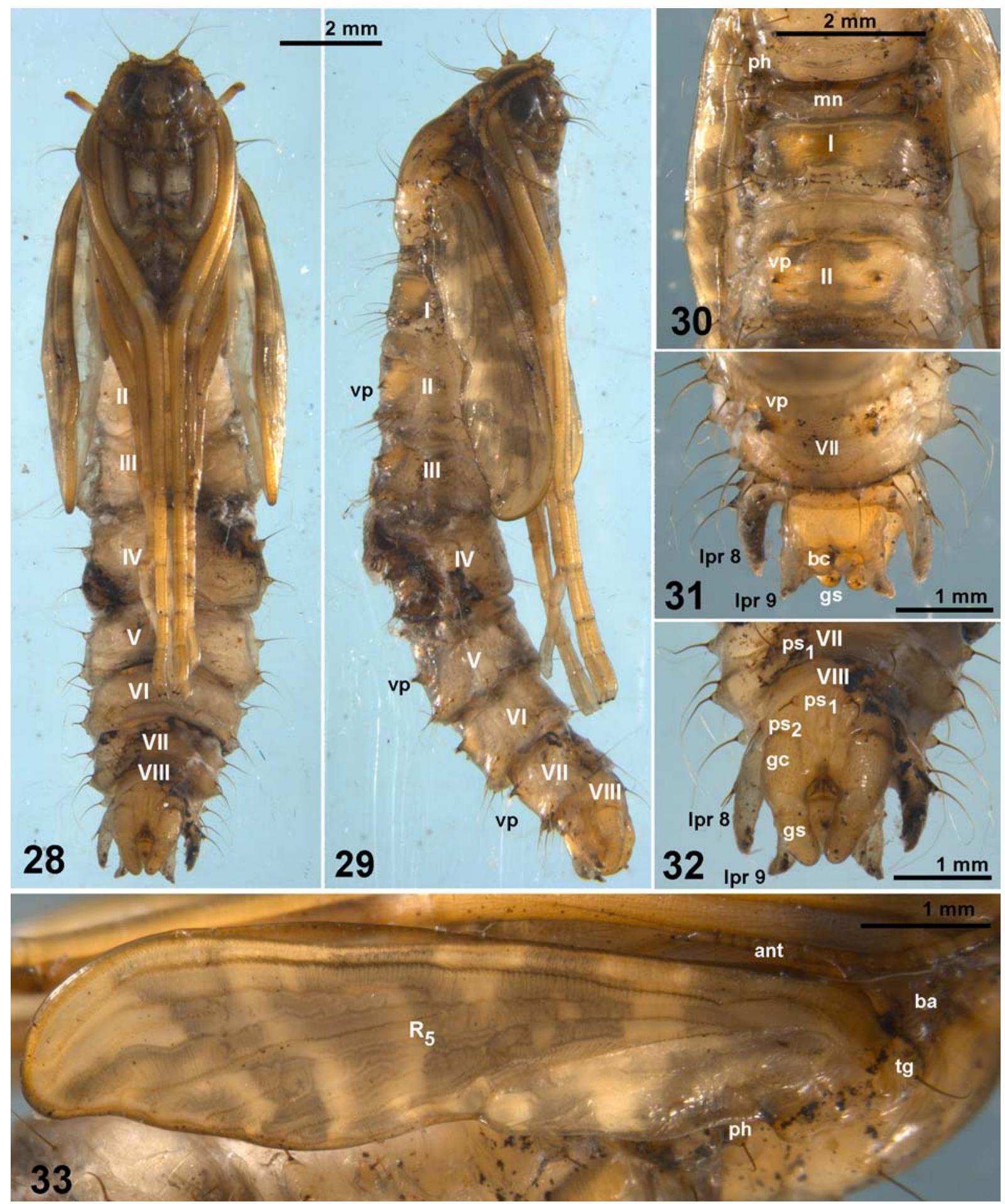

Figs 28-33. Male pupa of T. pictus \#3 (Alerce Costero): 28-29 — habitus ventrally and laterally; 30 — tergites I-II dorsally; $31-32$ cauda dorsally and ventrally; 33 - wing sheath.

Рис. 28-33. Куколка самца T. pictus \#3 (Алерсе Костеро): 28-29 — общий вид снизу и сбоку; 30 — тергиты I-II сверху; 3132 - конец брюшка сверху и снизу; 33 - крыловой чехол. 


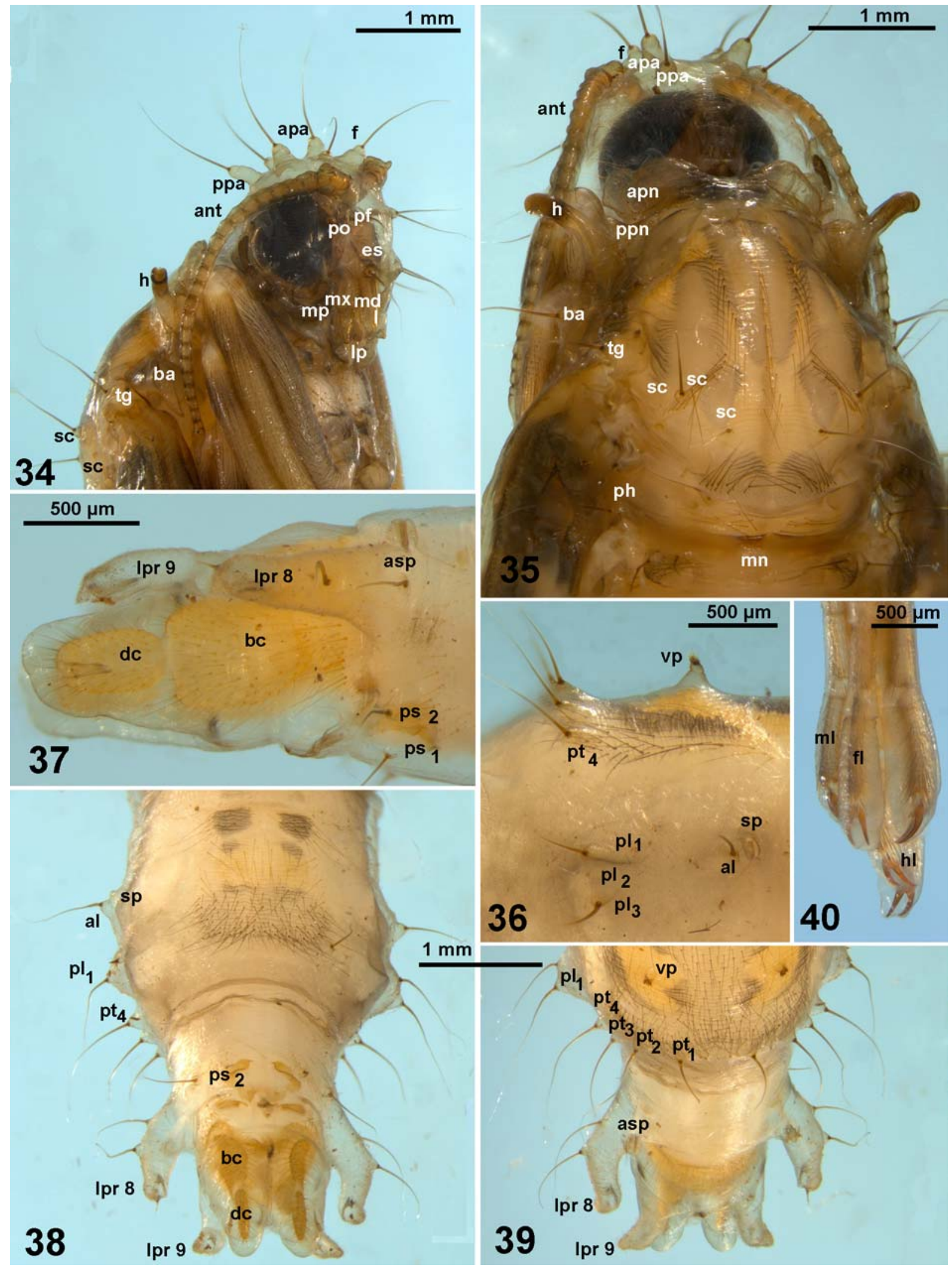

Figs 34-40. Female pupae of T. pictus: 34-39 — pupa \#2 (Alerce Andino): 34-35 — cephalothorax laterally and dorsally; 36 — VI segment laterally; 37-39 — cauda laterally, ventrally and dorsally; 40 - pupa \#6 (Alerce Costero), leg sheaths.

Рис. 34-40. Куколки самок T. pictus: 34-39 - куколка \#2 (Алерсе Андино): 34-35 — головогрудь сбоку и сверху; 36 — VI сегмент сбоку; 37-39 - конец брюшка сбоку, снизу и сверху; 40 - куколка \#6 (Алерсе Костеро), чехлы ног. 


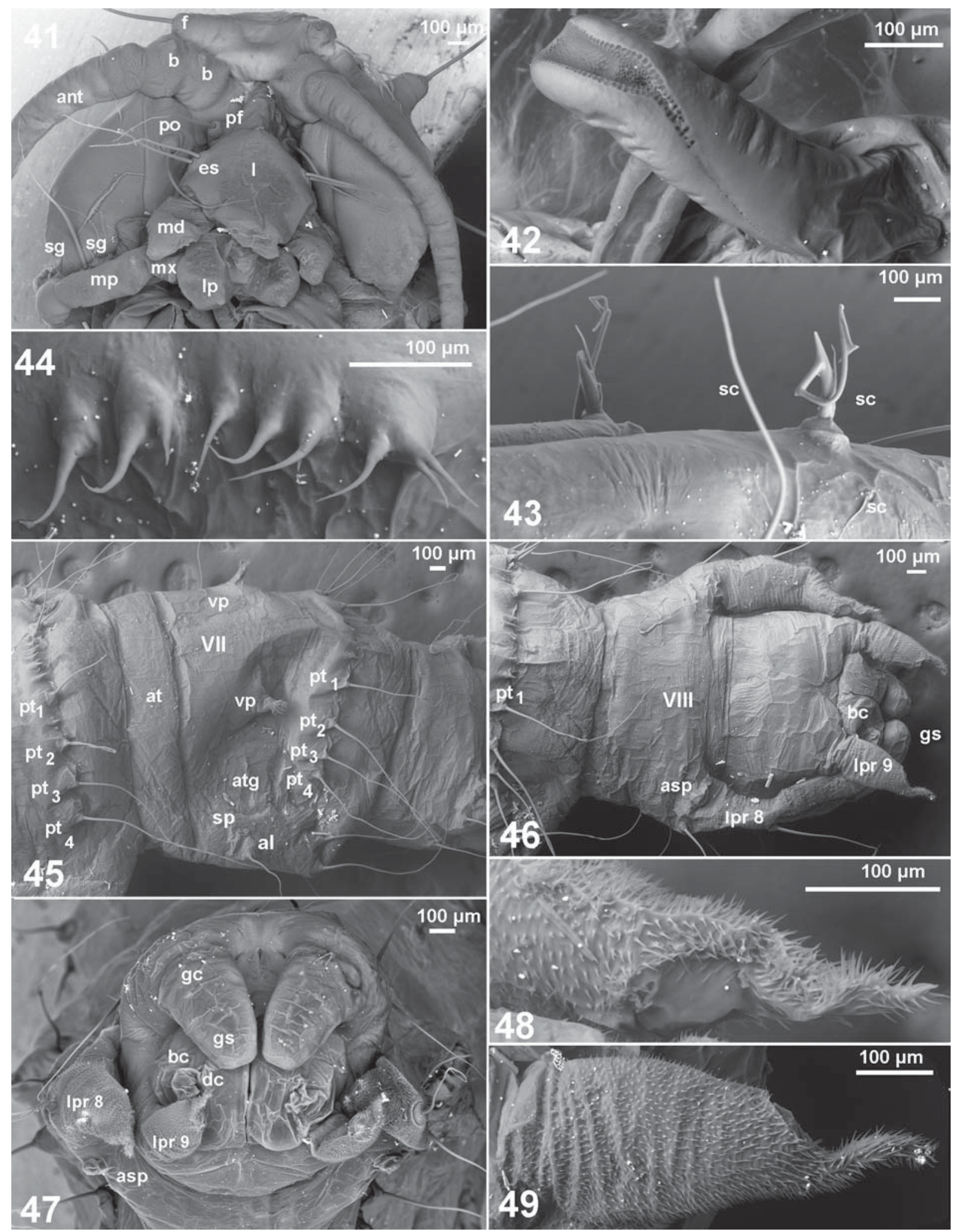

Figs 41-49. Details of male pupal exuvium of T. pictus \#1 (Alerce Andino; SEM, uncoated, BSE): 41 — face; 42 — thoracic horn; 43 scutal setae (fore pair abnormal); 44 — middle group of additional spinules on tergite V; 45 — tergites VI-VII; 46-47 — cauda dorsally and caudally; 48 - distal part of lateral process on tergite VIII; 49 - lateral process on tergite IX.

Рис. 41-49. Детали строения экзувия куколки самца T. pictus \#1 (Алерсе Андино; СЭМ, без напыления, BSE): 41 — лицо, 42 торакальный рог; 43 - скутальные хеты (первая пара - аберрантная); 44 - срединная группа шипиков на тергите V; 45 - тергиты VI-VII; 46-47 — конец брюшка сверху и сзади; 48 - конец бокового выроста на тергите VIII; 49 - боковой вырост на тергите IX. 
we failed to find such difference e.g. from Protoplasa described in detail by Crampton, except for unique verriculate protuberances and the absence of frontal horns (the latter shared with hyporheic Peringueyomyina); the unique leg sheath pattern with the shortest middle pair is apparently associated with life mode of adults rather than that of immatures.
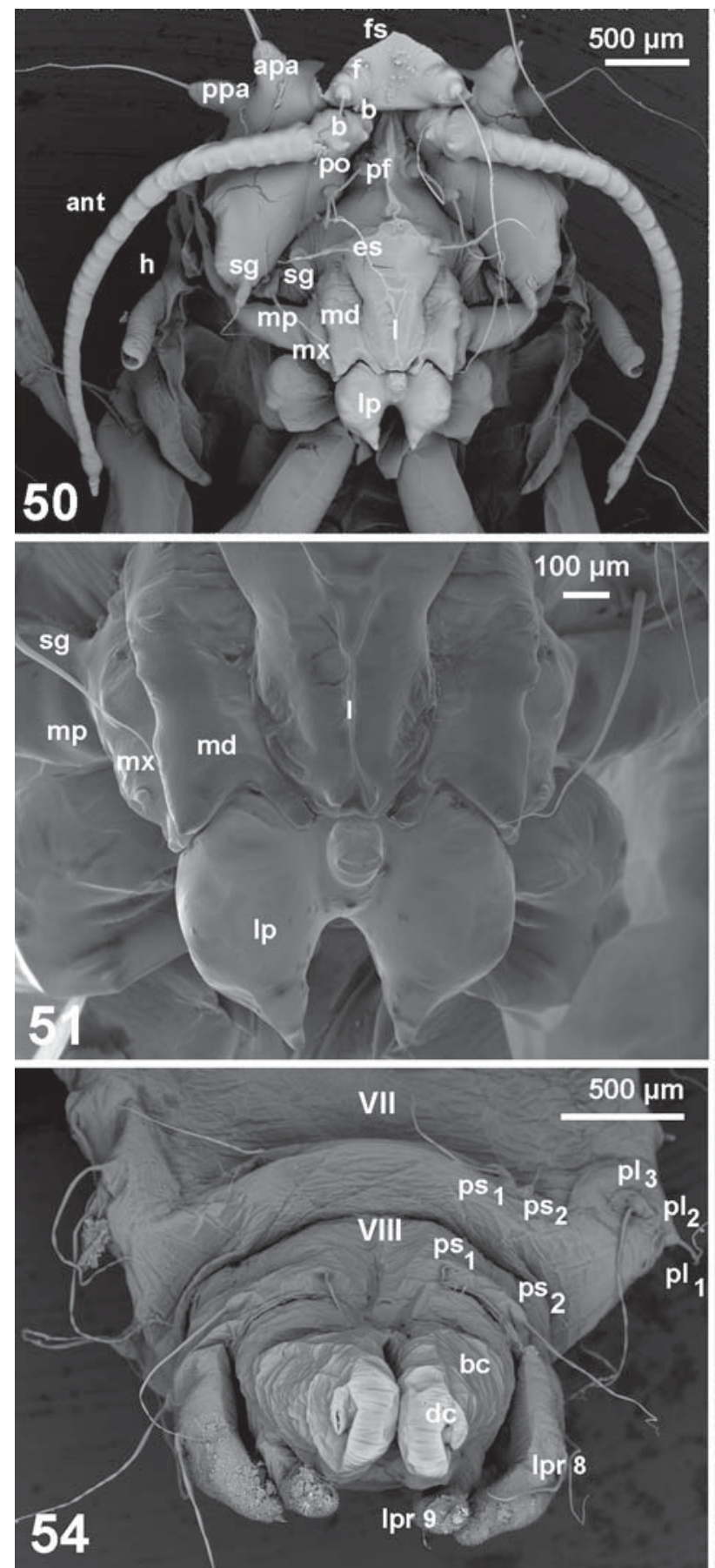

\section{Discussion}

Mandibles. Crampton [1930] discovered the small and rather indistinct processes on the pupal exuvium of Protoplasa and supposed that they probably are mandible sheaths, Knight [1964] also noted these small pro-

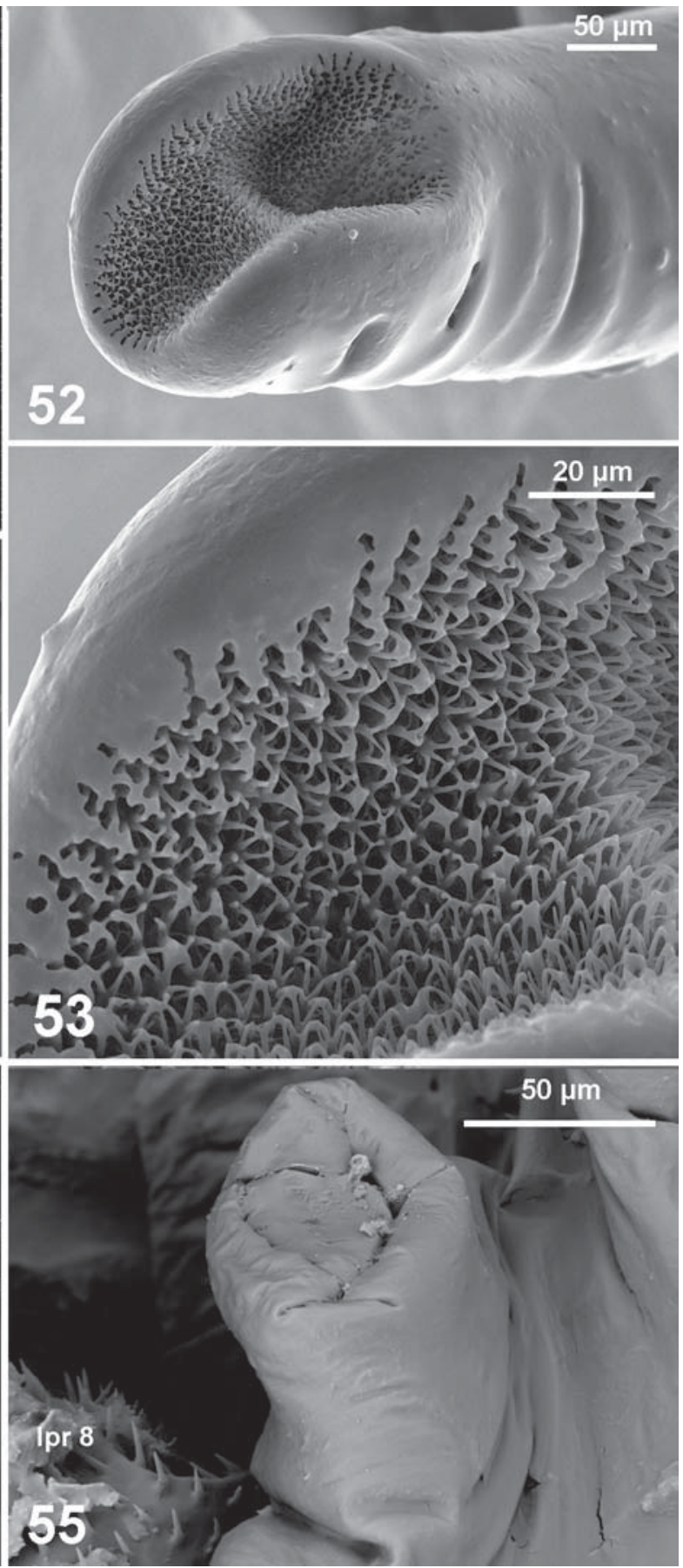

Figs 50-55. Details of female pupal exuvium of T. pictus \#5 (Alerce Costero; SEM, coated, BSE): 50 - face; 51 - mouthparts; 52 distal part of thoracic horn with plastron; 53 - part of plastron; 54 - cauda ventrally; 55 - postabdominal spiracle dorsally.

Рис. 50-55. Детали строения экзувия куколки самки T. pictus \#5 (Алерсе Костеро, СЭМ, напылено золотом, BSE): 50 - лицо; 51 - ротовые части; 52 - дистальная часть торакального рога с пластроном; 53 - часть пластрона; 54 - конец брюшка снизу; 55 - заднее дыхальце сверху. 


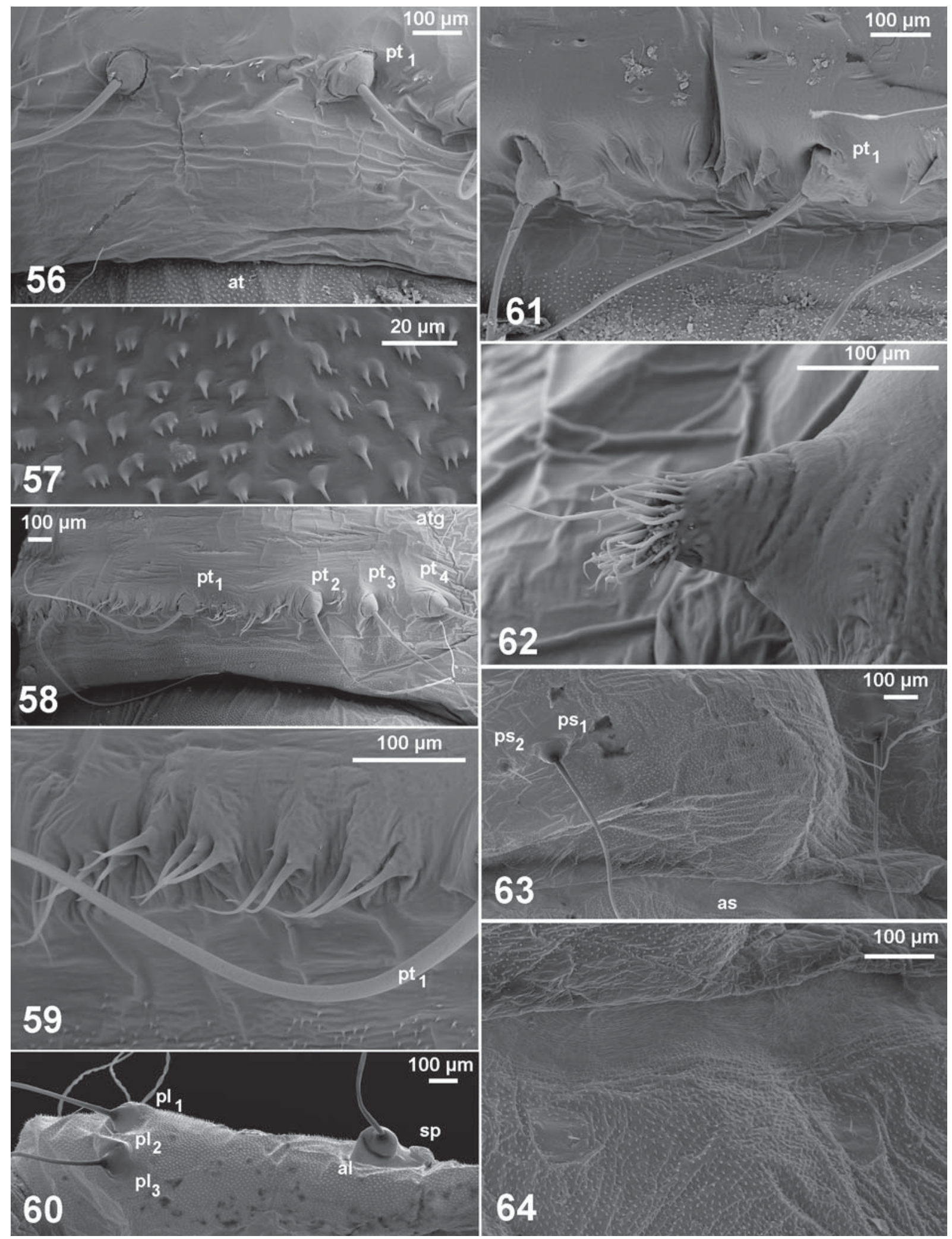

Figs 56-64. Chaetotaxy of female pupal exuvium of T. pictus \#5 (Alerce Costero; SEM, coated, BSE): 56 - tergite I; 57 - antetergite II; 58 - tergite II; 59 - middle group of additional spinules on tergite II; $60-$ pleurite V; 61 - middle group of additional spinules on tergite VI; 62 - verriculate protuberance on tergite V; 63 - posterior part of sternite V; 64 - antesternite VI.

Рис. 56-64. Хетотаксия экзувия куколки самки T. pictus \#5 (Алерсе Костеро, СЭМ, напылено золотом, BSE): 56 — тергит I; 57 антетергит II; 58 - тергит II; 59 - срединная группа шипиков на тергите II; 60 - плеврит V; 61 - срединная группа шипиков на тергите VI; 62 - щетконосный вырост на тергите V; 63 - задняя часть стернита V; 64 - антестернит VI. 
cesses, however no mandibles were found in a morphological study of the adult [Williams, 1933]. Later Downes, Colless [1967] briefly noted that in the adult Protoplasa mandibles are clearly developed, but small and unarmed, whereas the adult Radinoderus occidentalis (Alexander, 1925) possesses fully developed mouthparts, both mandibles and maxillae being broad thin blades and mandibles armed with very fine closely set teeth down the inner margin. Until now the adult mandibles were not illustrated or described in detail in any living Tanyderidae. However, in the minute, sandflylike tanyderid Dacochile Poinar et Brown, 2004 from Cretaceous Burmese amber the mandibles are narrow blades serrated along the apical margin [Poinar, 2012: fig. 14; Krzemiński et al., 2013].

In Tanyderus pupa the mandibular sheaths are relatively large, comparable with maxillary sheaths, and mandibles are visible inside the mature pupae of both sexes (Figs 34, 51). In the Tanyderus adult female (female \#4 was examined; Figs 20-21) the mandibles and maxillae are, like in Radinoderus, subequal, both broad, thin blades, mandibles being more sclerotized and denticulate, and maxillae less sclerotized and lacking marginal teeth. Such difference in degree of sclerotization is usual also between the more sclerotized stylets of blood-sucking Diptera, and the whole proboscis of female Tanyderus is not much unlike the type ancestral for Phlebotominae.

The female \#4 apparently died just after the emergence, with one wing not fully unfolded and one antenna abnormally short. The reared female \#5 kept alive in a mesh cage was rather inactive, mostly hanging from the roof on its fore and middle legs, though flew inside when disturbed. Our attempts to feed it failed, but it was drinking water and diluted honey from the pipette several times. This female didn't get down to the container with water and vegetables and died a week after the emergence, so we can add nothing about the feeding method of Tanyderus which is very interesting due to the full set of functional mouthparts.

Pupal chaetotaxy. The pattern and number of cephalothoracic setae in Tanyderus is basically the same as in Protoplasa, except for e.g. frontal setae $f$ tuberculate instead of sitting on well-developed frontal horns (= cephalic crest of Wood), epistomal setae es not sitting on epistomal processes (which are lacking as well as frontal horns), and subgenal setae $s g$ not close-set. The chaetotaxy of Peringueyomyina is not described in sufficient detail for comparison.

The setation of abdominal sternites in Tanyderus is similar to that in Protoplasa (a pair of posterior sternal setae $p s$, unequal on I-VII sternites and equal on the VIII sternite). However, the setation of tergites is distinct: in Protoplasa two strong anterior tergal setae on tergites IVII; in Tanyderus one thin anterior tergal seta atg and a verriculate protuberance $v p$ on each side situated much more medially, both level with anterior lateral setae $a l$ on pleurite as in Protoplasa (Figs 29-31, 45, 58, 62). So the pattern of tergal chaetotaxy is basically the same, but with the outer anterior tergal seta weakened and the inner one shifted mediad, strengthened and complicated. We failed to find the structures similar to verriculate protuberances in other dipteran pupae, in any case they are uncommon.

In the pupa of Protoplasa Crampton described 1 anterior lateral seta $a l$ just behind the spiracle and 3 subequal posterolateral setae $p l$ in the posterior row on pleurites I-VII. The similar pattern was found by us in Tanyderus larvae (also with subequal setae) [Lukashevich, Shcherbakov, 2014: figs 16, 18] and herein in its pupa, where both outer setae $p l$ are much stronger than the middle one (Figs 36,60). The arrangement of posterior tergal setae on the pupal tergites I-VII just before the posterior margin with a transverse row of 4 large tubercles on each side, 1 medial $p t$ and 3 lateral $p t_{2-4}$ (Figs 39, 45, 58), also follows the larval pattern. Conformity of larval and pupal chaetotaxy was demonstrated e.g. for abdominal setae in Ceratopogonidae [Lawson, 1951; Urbanek et al., 2015].

Legs of pupa. Fore legs of the adult Tanyderus are the longest due to the longest tarsi (fore leg/tarsus length $36 / 14 \mathrm{~mm}$ compared to $33 / 12 \mathrm{~mm}$ for middle and 34/11 $\mathrm{mm}$ for hind legs in female \#4), so that in its pupa the fore leg sheaths surpass the middle, but not the hind sheaths (in pupae the length of leg sheaths is compared by the position of their tips). Such pupal pattern with the sheaths of middle legs shortest is extremely rare in Diptera and described in Tanyderidae for the first time. Oosterbroek, Theobald [1991] considered the pattern with shortest middle sheaths (and all leg sheaths lying side by side as usual in Tipulomorpha) as a synapomorphy of Eriopterinae (Limoniidae) noting that it "apparently does not occur in other Nematocera."

The leg sheaths are longer in the Tanyderus male pupa (reaching to the abdominal segment VI) than in the female pupa (only to the base of V segment), and this can not be attributed to variable extension of the abdomen, because the male pupa and one of two female pupae were fixed dead and another female pupa alive.

Cauda of pupa. Crampton [1930] compared the pupa of Protoplasa with that of limoniid Eriocera Macquart, 1838 (now a subgenus of Hexatoma Latreille, 1809 ) and found a great similarity in their cephalothorax. It is interesting that the processes of abdominal apex are also widespread in Limoniidae Limnophilinae (former Hexatominae) often possessing three pairs of robust dorsal spines [Savchenko, 1986; Podeniene, Gelhaus, 2010]. Probably, the most similar pattern of abdominal apex with similar proportions of parts one can find in the pupa of Leptotarsus Guérin-Méneville, 1831, one of the basal genera of Tipulidae and the oldest known member of the family [Ribeiro, Lukashevich, 2014]. In male pupal exuvia of Leptotarsus (Longurio) testaceus (Loew, 1869) tergites VIII-IX likewise bear lateral processes (= dorsal lobes), all with small spines along length and "two dome-like protuberances between genital sheaths and dorsal lobes, each protuberance with distinct papillae at apex" [Gelhaus, Young, 
1995: 141, fig.16], so probably the tergite $X$ also bears the cerci with a rigid basal region and a softer distal one. The pair of lobes near male genitalic sheaths is well developed also in tipulids Brachypremna Osten-Sacken, 1887 and Ozodicera Macquart, 1834 [Gelhaus, Young, 1991, 1995]. However, reduction of male cerci is sometimes considered a synapomorphy of Tipulomorpha [Griffiths, 1990], so homology of the swellings needs further investigation.

The similar lateral processes are described also in one of the most ancient dipteran pupae Voltziapupa tentata Lukashevich et al., 2010 of uncertain affinity from the Middle Triassic of France [Lukashevich et al., 2010: fig. $2 \mathrm{~F}]$.

Tanyderidae and Ptychopteridae. Traditionally Tanyderidae and Ptychopteridae are considered to be closely related [Hennig, 1973; Wood, Borkent, 1989; Oosterbroek, Courtney, 1995; Shcherbakov et al., 1995], but some authors place them even into the different infraorders. Recently "no evidence of sister group relation" was discovered in the male genital tract of Tanyderidae lacking the synapomorphy grouping Ptychopteridae with Culicomorpha and Bibionomorpha [Borkent, Sinclair, 2012]. Indeed up to now only one character was suggested as a synapomorphy linking Tanyderidae and Ptychopteridae, the clasping organ on male tarsi tarsomere IV with basal swelling bearing tufts of setae opposite to tarsal claws (present in Chilean Araucoderus, pers. obs.).

Crampton [1926] discovered a projection on the halter of fossil tanyderid Macrochile spectrum Loew, 1850 (Baltic amber, Eocene) and supposed that it may be a precursor of the prehalter - a peculiar appendage from the halter base in Ptychopteridae, considered to be unique within the Diptera [Wood, Borkent, 1989]. We compared halters of extinct Macrochile and extant Tanyderus and Araucoderus and have found very similar short projections, positioned at the same place as prehalters of Ptychoptera (Figs 22-27), but tanyderid projections are not so well developed, so we agree with Crampton's suggestion. In the case the presence of the prehalter in Tanyderidae can be considered a synapomorphy with Ptychopteridae.

ACKNOWLEDGEMENTS. We are deeply indebted to Dr. Mario Elgueta (National Museum of Natural History, Santiago) and the CONAF staff of the Alerce Andino and Alerce Costero national parks for facilitating our field work in Chile, with special thanks to Walther Rodríguez Cárdenas for hospitality and creating the perfect positive atmosphere for our work. We also thank Roman Rakitov (Borissiak Paleontological Institute RAS, Moscow) for helping us take scanning electron images and other assistance, Mikhail Chertoprud (Moscow State University) for collecting some larvae, Ruben Isai Madriz (Iowa State University) for information about other records of Tanyderidae from Chile, Virginija Podeniene (Vilnius University) for helpful comments, Wieslaw Krzemiński (Institute of Systematics and Evolution of Animals, Krakow) for loaning us adults of recent Ptychoptera and Cenozoic Macrochile, and Vladimir Blagoderov
(Natural History Museum, London) for the assistance in obtaining important publications.

The research was partly supported by the Russian Foundation for Basic Research, project no. 13-04-01839 and 1604-01498.

\section{References}

Alexander C.P. 1913. A revision of the South American dipterous insects of the family Ptychopteridae // Proceedings of the United States National Museum. Vol.44. P.331-335.

Alexander C.P. 1927. Diptera fam. Tanyderidae // Genera Insectorum. Vol.189. P.1-13.

Alexander C.P. 1929. Diptera of Patagonia and South Chile. Part I. Crane-flies (Tipulidae, Trichoceridae, Tanyderidae). London: British Museum (Natural History). 240 pp.

Alexander C.P. 1930a. Observation on the dipterous family Tanyderidae// Proceedings of the Linnean Society of New South Wales. Vol.55. P.221-232.

Alexander C.P. 1930b. Tanyderus pictus Philippi (Fam. Tanyderidae, Ord. Diptera) // Revista Chilena de Historia Natural. Vol.34. P.110-113.

Alexander C.P. 1936. The distribution of Tanyderus pictus Ph. (Fam. Tanyderidae, Ord. Diptera) // Revista Chilena de Historia Natural. Vol.39. P.86-87.

Ansorge J. 1994. Tanyderidae and Psychodidae (Insecta: Diptera) from the Lower Jurassic of northeastern Germany// Paläontologische Zeitschrift. Vol.68. P.199-209.

Borkent A., Sinclair B.J. 2012. The male genital tract of Axymyiidae and Tanyderidae (Diptera) // Canadian Entomologist. Vol.144. P.266-272.

Colless D.H., McAlpine D.K. 1970. Chapter 34. Diptera // Mackerras I.M. (ed.). The Insects of Australia. Carlton, Victoria: Melbourne University Press. P.656-740.

Crampton G.C. 1926. The external anatomy of the primitive tanyderid dipteran Macrochile spectrum Loew, preserved in Baltic amber// Bulletin of the Brooklyn Entomological Society. Vol.21. P.1-14.

Crampton G.C. 1930. Some anatomical details of the pupa of the archaic tanyderid dipteron Protoplasa fitchii, O.S. // Proceedings of the Entomological Society of Washington. Vol.32. P.83-98.

Downes J.A., Colless D.H. 1967. Mouthparts of the biting and bloodsucking type in Tanyderidae and Chironomidae (Diptera) // Nature. Vol.214. P.1355-1356.

Eskov K.Y., Lukashevich E.D. 2015. On the history of ranges of two relict nematoceran families, Ptychopteridae and Tanyderidae (Insecta: Diptera): a biogeographical puzzle // Russian Entomological Journal. Vol.24. P.257-270.

Exner K., Craig D.A. 1976. Larvae of Alberta Tanyderidae (Diptera: Nematocera) // Quaestiones Entomologicae. Vol.12. P.219-237.

Gelhaus J.K., Young C.W. 1991. The immature instars and biology of the crane fly genus Brachypremna Osten Sacken (Diptera: Tipulidae) // Proceedings of the Entomological Society of Washington. Vol.93. P.613-621.

Gelhaus J.K., Young C.W. 1995. Pupae of the crane fly genus Leptotarsus (Diptera: Tipulidae) in the New World, with discussion of the monophyly of the genus // Annals of Carnegie Museum. Vol.64. P.135-145.

Griffiths G.C.D. 1990. Book review: Manual of Nearctic Diptera. Volume 3. J.F. McAlpine and D.M.Wood (editors) // Quaestiones Entomologicae. Vol.26. P.117-130.

Hennig W. 1973. Ordnung Diptera (Zweiflügler) // Handbuch der Zoologie. Vol.4(2). Pt.2/31. P.1-337.

Hinton H.E. 1966. The spiracular gill of the fly Eutanyderus (Tanyderidae) // Australian Journal of Zoology. Vol.14. P.365-369.

Judd D.D. 2004. Insecta: Diptera, Tanyderidae // Yule C.M., Yong H.S. (eds). Freshwater Invertebrates of the Malaysian Region. Kuala Lumpur: Academy of Sciences Malaysia. P.626-633.

Knight A. 1964. Description of the tanyderid pupa Protanyderus margarita Alexander from Colorado // Entomological News. Vol.75. P.237-241 
Kovalev V.G. 1984. [Stages and factors in the historical development of the dipteran fauna ] // Chernov Y.I (ed.) Faunogenesis and Phylocenogenesis. Moscow: Nauka. P.138-153 [in Russian].

Krivosheina N.P., Mamaev B.M. 1967. [Keys to Larvae of WoodInhabiting Diptera.] Moscow: Nauka. 367 pp [in Russian].

Krzemiński W., Judd D.D. 1997. Family Tanyderidae // Papp L., Darvas B. (eds). Contributions to a Manual of Palaearctic Diptera (with special reference to flies of economic importance). Vol.2. Nematocera and Lower Brachycera. Budapest: Science Herald. P.281-289.

Krzemiński W., Azar D., Skibińska K. 2013. Nannotanyderus ansorgei $\mathrm{sp} . \mathrm{n}$., the first member of the family Tanyderidae from the Lebanese amber (Lower Cretaceous) // Insect Evolution in an Amberiferous and Stone Alphabet: Proceedings of the 6th International Congress on Fossil Insects, Arthropods and Amber. P.131-143.

Lawson J.W.H. 1951. The anatomy and morphology of the early stages of Culicoides nubeculosus Meigen (Diptera: Ceratopogonidae $=$ Heleidae) $/ /$ Proceedings of the Royal Entomological Society of London. Vol.102. P.511-570.

Lukashevich E.D., Przhiboro A.A., Marchal-Papier F., GrauvogelStamm L. 2010. The oldest occurrence of immature Diptera (Insecta), Middle Triassic, France // Annales de la Société Entomologique de France. Vol.46. P.4-22.

Lukashevich E.D., Krzemiński W. 2009. New Jurassic Tanyderidae (Diptera) from Asia with first find of larvae // Zoosymposia. Vol.3. P.155-172.

Lukashevich E.D., Shcherbakov D.E. 2014. First description of Tanyderidae (Diptera) larvae from South America // Russian Entomological Journal. Vol.23. No.2. P.121-138.

Oosterbroek P., Courtney G. 1995. Phylogeny of the nematocerous families of Diptera (Insecta) // Zoological Journal of the Linnean Society. Vol.115. P.267-311.

Oosterbroek P., Theowald B. 1991. Phylogeny of the Tipuloidea based on characters of larvae and pupae (Diptera, Nematocera), with an index to the literature except Tipulidae // Tijdschrift voor Entomologie. Vol.134. P.211-267.

Philippi R.A. 1865. Aufzählung der chilenischen Dipteren // Verhandlungen der kaiserlich-königlichen zoologisch-botanischen Gesellschaft in Wien. Vol.15. P.597-782.

Pilgrim R.L.C. 1990. A role for the amateur in New Zealand entomology // New Zealand Entomologist. Vol.13. P.1-6.
Podeniene V., Gelhaus J.K. 2010. The last instar larvae and pupae of Mongolian Limnophilinae crane flies from genera Eloeophila, Limnophila and Phylidorea (Diptera, Limoniidae) // Proceedings of the Academy of Natural Sciences of Philadelphia. Vol.159. P.185-204.

Podeniene V., Gelhaus J.K. 2013. Larva of Protanyderus stackelbergi Savchenko, 1971 (Diptera: Ptychopteromorpha, Tanyderidae) from Mongolia // Proceedings of the Academy of Natural Sciences of Philadelphia. Vol.162. P.125-132.

Poinar G., Jr. 2012. Desiomorphs in Amber // American Entomologist. Vol.58. P.214-222.

Ribeiro G.C., Lukashevich E.D. 2014. New Leptotarsus from the Early Cretaceous of Brazil and Spain: the oldest member of the family Tipulidae (Diptera) // Zootaxa. Vol.3753. P.347-363.

Savchenko E.N. 1986. [Limoniid Flies.] Fauna Ukraini. Vol.14. No.2. Kiev: Naukova Dumka. 380 pp. [in Russian].

Shcherbakov D.E., Lukashevich E.D., Blagoderov V.A. 1995. Triassic Diptera and initial radiation of the order // International Journal of Dipterological Research. Vol.6. P.75-115.

Skibińska K., Krzemiński W., Coram R.A. 2014. Discovery of the most ancient member of family Tanyderidae (Diptera) from the Lower Jurassic (Sinemurian) of England // Zootaxa. Vol.3857. P.125-130.

Urbanek A., Richert M., Kapusta M. 2015. Metamorphic changes in abdominal spines of Forcipomyia nigra pupae (Diptera: Ceratopogonidae) // Arthropod Structure \& Development. Vol.44. P.554-567.

Wihlm M.W., Courtney G.W. 2011. The distribution and life history of Axymyia furcata McAtee (Diptera: Axymyiidae), a wood inhabiting, semi-aquatic fly // Proceedings of the Entomological Society of Washington. Vol.113. P.385-398.

Williams I.W. 1933. The external morphology of the primitive tanyderid dipteron Protoplasa fitchii O.S., with notes on the other Tanyderidae // Journal of the New York Entomological Society. Vol.41. P.1-35.

Wood H.G. 1952. The crane-flies of the south-west Cape (Diptera, Tipuloidea) // Annals of the South African Museum. Vol.39. P.1-327.

Wood D.M., Borkent A. 1989. Phylogeny and classification of the Nematocera // McAlpine J.F. (ed.). Manual of Nearctic Diptera. Vol.3. Ottawa: Research Branch, Agriculture Canada. P.13331370 . 